\title{
MAJALAH
}

Vol. IX Edisi September 2013
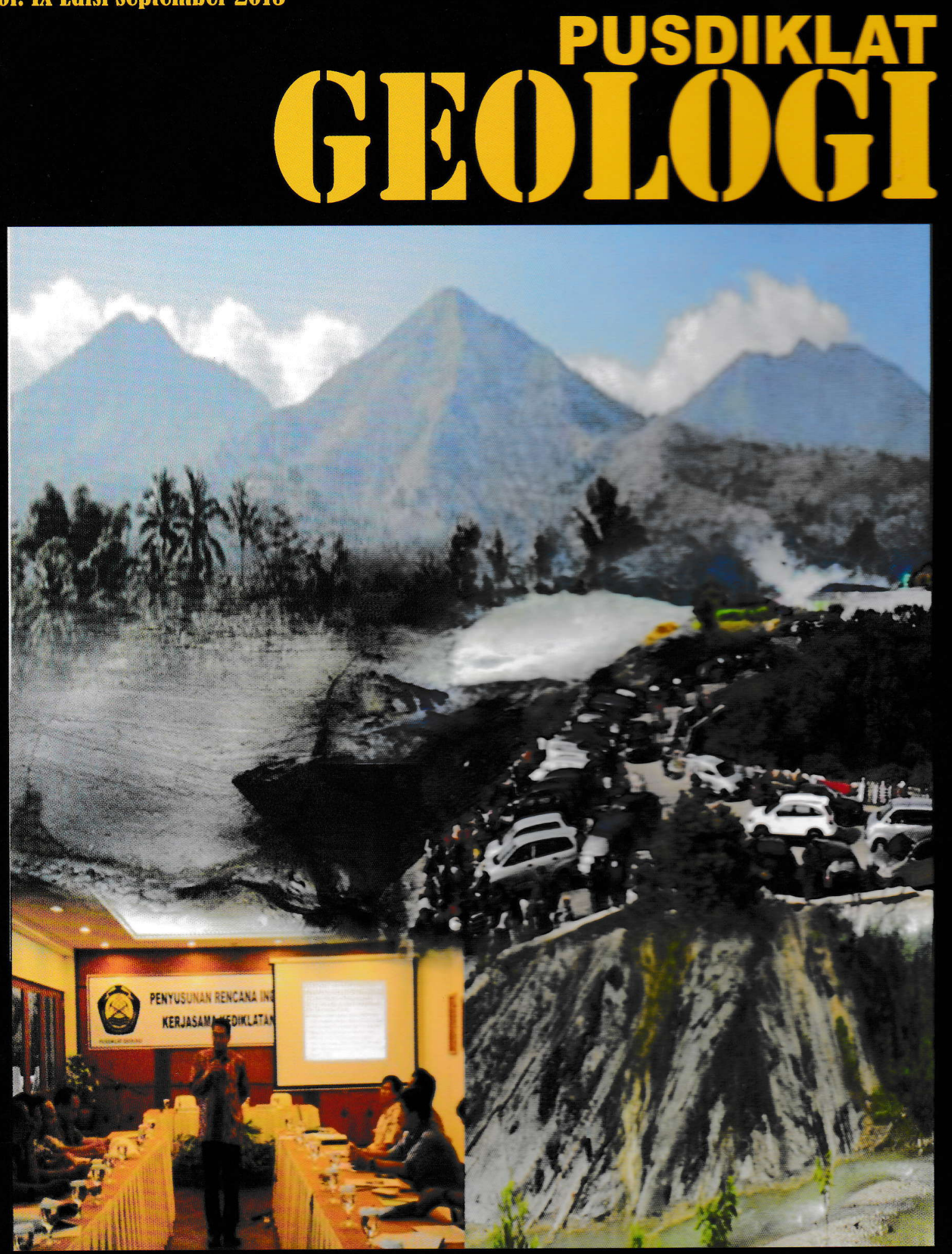

OPINI CRRTIA GEOLOCI TNE GEOUNIK PARISTIWA OANE 


\section{Daftar Isi}

Vol. IX Edisi September 2013

\section{DARI REDAKSI 2}

\section{OPINI 3}

Menjaga Karst Maros-pangkep Sebagai Warisan Dunia

(Tinjauan dari aspek Geologi Lingkungan dan Geowisata) 3

Pengembangan Sumber Daya Manusia Pdam (Studi Kasus PDAM Kota Pontianak) 11

\section{CERITA GEOLOGI 17}

Penyelidikan Geologi Teknik Untuk Pengembangan Wilayah Pantai 17

Gunung Sadahurip Desa Sukahurip, Kec. Pangatikan, Kab. Garut, Jawa Barat 23

Kepemimpinan Transformasional Dalam Penanggulangan Bencana Gunung Api 33

Mengenal Daerah Sulit Air 39

\section{INFO 41}

Dibalik Pesona Bukit Lancang 41

Arahan Pengelolaan Air Tanah 47

Batako Tuf Pasiran Sebagai Batako Alternatif Untuk Bahan Bangunan

di Daerah Liwa, Lampung Barat 51

Persiapan Dalam Rangka Sertifikasi Widyaiswara 59

Belajar Secara Online Di Era Teknologi Dan Informasi Dan Komunikasi:

Pengalaman Sebagai Siswa Cousera Tempat Belajar Online Terbuka 62

\section{GEOUNIK 68}

Selamatkan Tangkuban Perahu 68

\section{PERISTIWA 72}

Fungsi Rekreatif Dalam Program Diklat 72

Rencana Induk Kerjasama Pusdiklat Geologi 75

\section{OASE 79}

Sebuah Analisis dan Upaya Pencegahan dari 1091 PNS

Yang Terkena Kasus Hukum, 60 Persen PNS Terlilit Kasus Korupsi 79

Penanggungjawab : Dr. Ir. Bambang Tjahjono Setiabudi, M.Sc., Redaktur : Ir. M. Rum Budi Susilo, MT., Dra. Ratih Wiratnawati, Johan Budi Winarto, ST., MT., Ani Maliani, ST., MT., Fiati Nurmaya, ST., MT., Editor : R. Yudi Pratama, ST., M.Ed., Ir. Yunianto Djatmiko, Yudi Rahayudin, ST., MT., Asep Rohman, ST., MT., Anita Ariestiyani, S's., Desain Grafis : Adang Saputra, S.Si Komp. M.Si., Fotografer : Denny Lumban Raja, S.Kom. MT., Sekretariat : Kokom Siti Komariah, SH., Astrid Nur Perwita, A.Md., Rajiman. Alamat Redaksi: Jl. Cisitu Lama No. 37 Bandung 40135 Tlp.(022) 2502428 Fax. (022) 2506224, e-mail: publikasi@pusdiklatgeologi.esdm.go.id 


\title{
BATAKO TUF PASIRAN SEBAGAI BATAKO ALTERNATIF UNTUK BAHAN BANGUNAN DI DAERAH LIWA, LAMPUNG BARAT
}

\author{
${ }^{\text {a} P r a h a r a ~ I q b a l ~}$
}

${ }^{a}$ UPT Loka Uji Teknik Penambangan dan Mitigasi Bencana, LIPI Pekon Padang Dalom, Kecamatan Balik Bukit, Liwa, Lampung Barat Tlp: 085369050356, Email:

praharaiqbal@yahoo.com

\begin{abstract}
ABSTRAK
Pembangunan di suatu daerah akan berkaitan langsung dengan pemanfaatan sumber daya bahan galian untuk bahan bangunan. Eksploitasi bahan galian untuk bangunan di daerah perkotaan terus dilakukan seiring dengan kebutuhan yang terus meningkat. Sebagian besar kondisi lokasi eksploitasi bahan galian saat ini semakin kritis hingga di beberapa tempat mengakibatkan kerusakan lingkungan. Untuk mengatasi masalah tersebut perlu dilakukan pemanfaatan bahan galian alternatif pengganti bahan galian yang sudah ada saat ini. Uji kuat tekan bebas terhadap batako tuf pasiran telah dilakukan. Hasil percobaan uji kuat tekan ini menunjukkan nilai kuat tekan yang bervariasi, yang secara keseluruhan di atas nilai standar bahan bangunan, yaitu berkisar $16-61 \mathrm{Kg} / \mathrm{Cm}^{2}$
\end{abstract}

Kata kunci: Bahan galian alternatif, batako tuf, uji kuat tekan bebas

\begin{abstract}
Development of a region will be directly related to the utilization of mineral resources for building materials. Exploitation of minerals for buildings in urban areas continues to be done in line with the growing need. Most of the site conditions of exploitation of minerals is critical, in some places lead to environmental damage. To overcome these problems it is necessary to use alternatives to extractive minerals that already exist today. Free strength test of sandy tuff blocks has been done. Results of this experimental strength test, shown various compressive strength values, in which all of the values above the values of standard building materials, which ranges from $16-61 \mathrm{~kg} / \mathrm{cm}^{2}$
\end{abstract}

Keywords: Batako sandy tuff, Free strength test

\section{PENDAHULUAN}

Eksploitasi bahan galian untuk bangunan di daerah perkotaan terus dilakukan seiring dengan kebutuhan yang terus meningkat. Contoh bahan galian yang sangat dibutuhkan untuk pembuatan bahan bangunan adalah lempung, pasir, dan kerikil. Sebagian besar kondisi lokasi eksploitasi bahan galian saat ini semakin kritis hingga di beberapa tempat mengakibatkan kerusakan lingkungan. Untuk mengatasi masalah tersebut 
perlu dilakukan pemanfaatan bahan galian alternatif pengganti bahan galian yang sudah ada saat ini.

Kabupaten Lampung Barat adalah kabupaten termuda di Propinsi Lampung yang beribukota di Liwa. Kabupaten ini diresmikan pada tahun 1991 (Anwar dkk., 1994). Sebagai ibukota kabupaten baru, maka tidak akan dipungkiri pembangunan di kota ini akan berkembang pesat. Pembangunan suatu daerah akan berkaitan langsung dengan pemanfaatan sumber daya yang dimiliki daerah tersebut, khususnya sumber daya alam bahan galian untuk bahan bangunan.

Di daerah Lampung Barat, bahan galian tuf pasiran dihasilkan dari aktivitas gunungapi muda (Kuarter) yang tersebar di bagian utara, tengah, dan selatan kota Liwa, mulai dari daerah Kalianda (Lampung Selatan), kota Liwa (Lampung Barat), hingga Danau Ranau (Lampung Barat). Rata-rata bahan galian ini memiliki ketebalan +75 meter dan membentuk morfologi perbukitan

(Anwar dkk., 1994).

\section{LANDASAN TEORI 1.}

\section{Batako}

Batako terdiri atas berbagai bentuk dan ukuran. Istilah batako berhubungan dengan bentuk persegi panjang yang digunakan untuk dinding beton (Müller dkk., 2006). Batako digolongkan menjadi dua kelompok utama, yakni batako padat dan batako berlubang (Müller dkk., 2006).

\section{Pembuatan Benda Uji Berbentuk Balok Persegi}

Benda uji berbentuk balok persegi dibuat dari contoh blok dengan tahapan sebagai berikut (SNI 2848:2008):

a. Mengambil contoh blok dan membuka pembungkus allumunium foil berikut lilin atau parafin yang menutupi permukaannya.

b. Menggambar pola rencana pemotongan contoh blok berdasarkan orientasi contoh blok yang disesuaikan dengan kondisi geologi daerah penelitian dan rencana beban uji.

c. Memotong contoh inti dengan menggunakan gergaji batu sesuai pola yang digambarkan menjadi benda uji berbentuk balok persegi yang diinginkan. 
d. Menghaluskan secara bertahap permukaan penampang atas dan bawah benda uji dengan menggunakan mesin poles, dimulai dengan pemoles kasar yaitu ampelas dan dilanjutkan dengan pemoles halus yaitu serbuk korundum.

e. Mengukur kerataan permukaan penampang benda uji dengan menggunakan alat pengukur kerataan.

f. Mengukur dimensi benda uji dengan mengunakan jangka sorong.

g. Memberi label dengan keterangan selengkapnya pada benda uji yang telah dibuat dengan perbandingan $\mathrm{D}: \mathrm{H}=2: 1$ pada suatu tempat yang mempunyai temperatur tetap antara $20-26^{\circ} \mathrm{C}$ dan angka kelembaban disesuaikan dengan ruangan.

\section{Uji Kuat Tekan Bebas}

Uji kuat tekan bebas dilakukan untuk mendapatkan nilai kekuatan suatu benda dalam keadaan bebas sampai mencapai keruntuhan atau pecah (Shirley, 1994).

Alat - alat yang digunakan:

- Alat tekan

- Alat pengeluar contoh

- Arloji pembaca

- Alat pencatat waktu

- Timbangan

\section{METODOLOGI PENELITIAN 1.}

\section{Daerah penelitian}

Secara geografis daerah penelitian berada pada koordinat $104^{0} 23,45^{\prime} 00^{\prime \prime}-104^{0}$ $31^{\prime} 39,6^{\prime \prime}$ bujur timur dan $04^{0} 55^{\prime} 51,7^{\prime \prime}-05^{0} 02^{\prime} 113^{\prime \prime}$ lintang selatan dengan ketinggian daerah rata-rata $300-800 \mathrm{~m}$ di atas permukaan laut, berupa perbukitan yang bergelombang, lembah - lembah, dan sebagian pedataran (Gambar 1). Secara administratif termasuk ke dalam wilayah Kabupaten Lampung Utara dan Kabupaten Lampung Barat. 


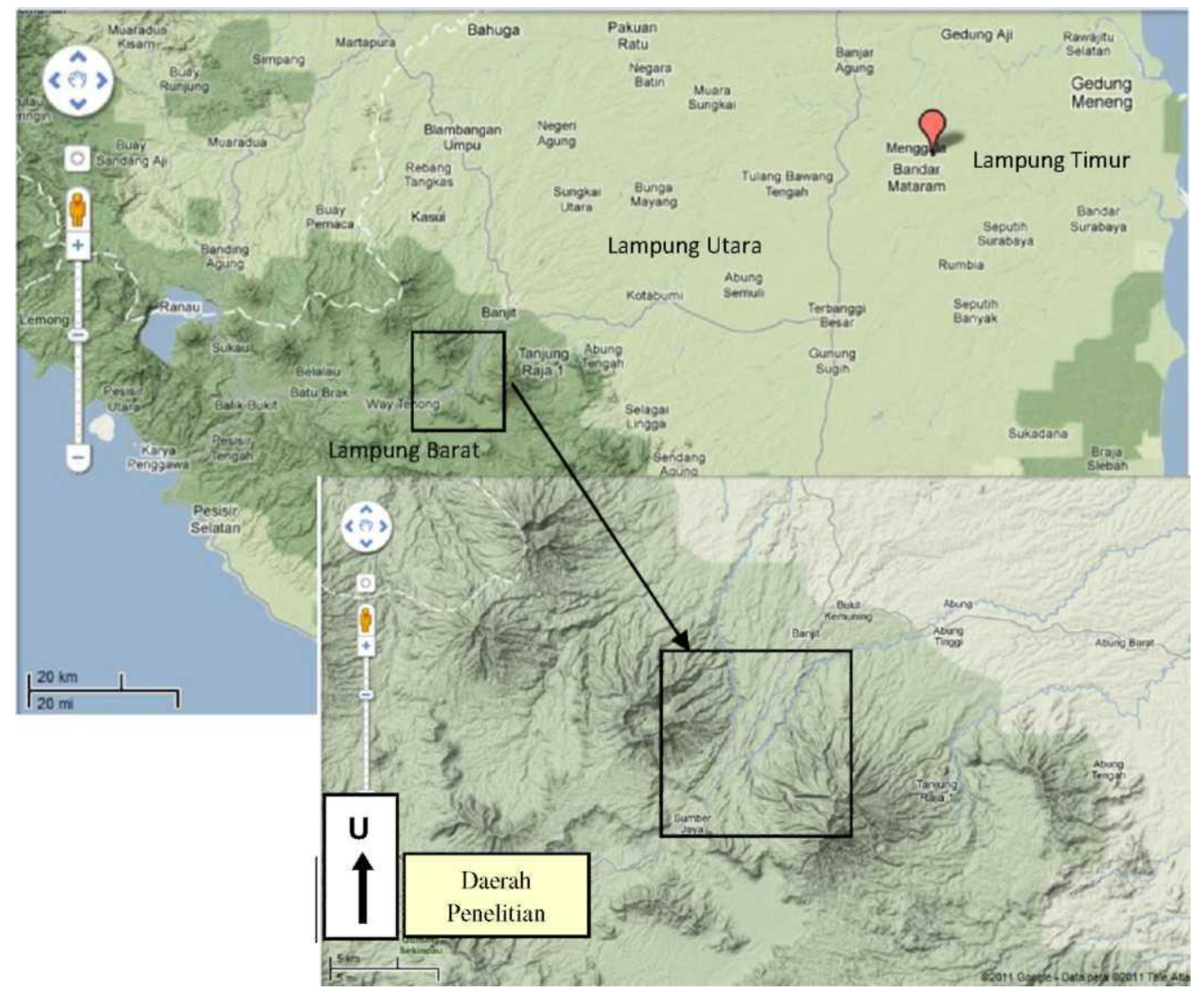

\section{Gambar 1. Peta Lokasi Daerah Penelitian (http://www.maps.google.co.id diakses pada tanggal 1 April 2013)}

\section{Metode Penelitian}

Metode penelitian yang digunakan dalam penelitian ini adalah studi literatur, survei lapangan, pembuatan batako, dan uji kuat tekan bebas. Studi literatur dilakukan untuk mengetahui kondisi geologi dan sifat keteknikan tuf pasiran yang sudah diteliti oleh peneliti terdahulu. Untuk validasi dan pengambilan sampel tuf pasiran di daerah penelitian, dilakukan survei lapangan dengan cara pengamatan langsung pada singkapan dan pengambilan contoh. Penentuan lokasi titik pengambilan contoh dilakukan secara random sampling pada lokasi pengamatan. Sementara, pembuatan batako dilakukan

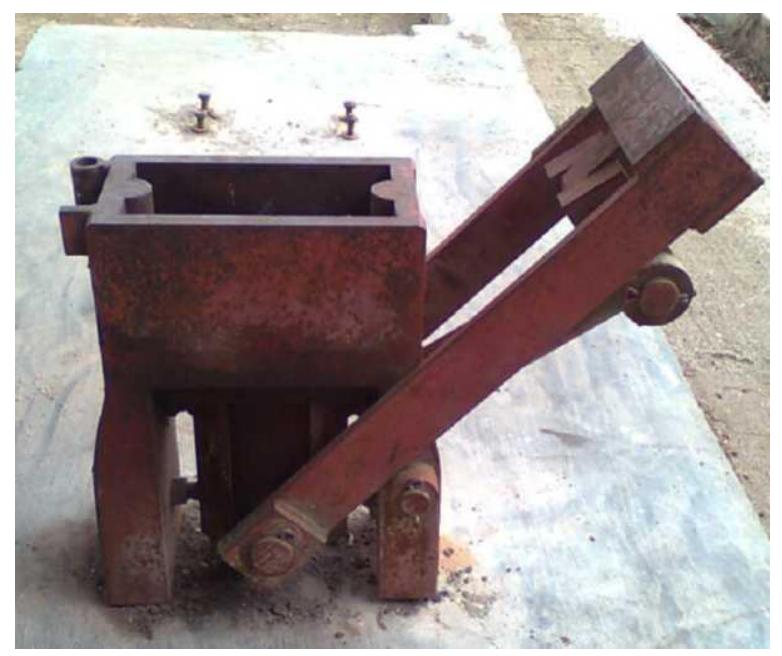

Gambar 2. Alat Pembuat Batako 
melalui pencampuran tuf pasiran dengan bahan lain seperti kapur, semen, dan bambu dengan menggunakan tiga formula. Bahan yang digunakan untuk pembuatan batako merupakan bahan yang banyak ditemukan di daerah penelitian dan dengan tujuan untuk memanfaatkan bahan yang ada serta membuat batako yang sesuai dengan standar bangunan. Semua bahan dicampur dan diaduk dalam keadaan kering. Kemudian campuran tersebut dicetak sehingga berbentuk batako (Gambar 2) dan ditiriskan selama 21 hari (penirisan dilakukan tidak dibawah terik matahari untuk menghindari retakan akibat pengeringan yang mendadak). Batako yang sudah jadi kemudian dibuat benda uji untuk dilakukan uji kuat tekan bebas. Uji kuat tekan bebas dilakukan untuk mengetahui kekuatan batako hingga didapatkan sebuah formula perbandingan yang memenuhi standar bahan bangunan.

\section{HASIL DAN PEMBAHASAN 1.}

\section{Geologi Tuf Pasiran}

Berdasarkan hasil pengamatan langsung di lapangan, tuf pasiran berwarna segar abu-abu sampai abu-abu kecokelatan, tekstur sedang sampai kasar, bentuk butir membundar sampai sangat membundar, terpilah baik, permeabilitas baik, kemas terbuka, dapat diremas, mengandung mika dan batuapung, dan lepas-lepas (Gambar 3). Kenampakan di lapangan tuf pasiran memiliki ketebalan $+75 \mathrm{~m}$, membentuk morfologi perbukitan berlereng sedang - terjal.

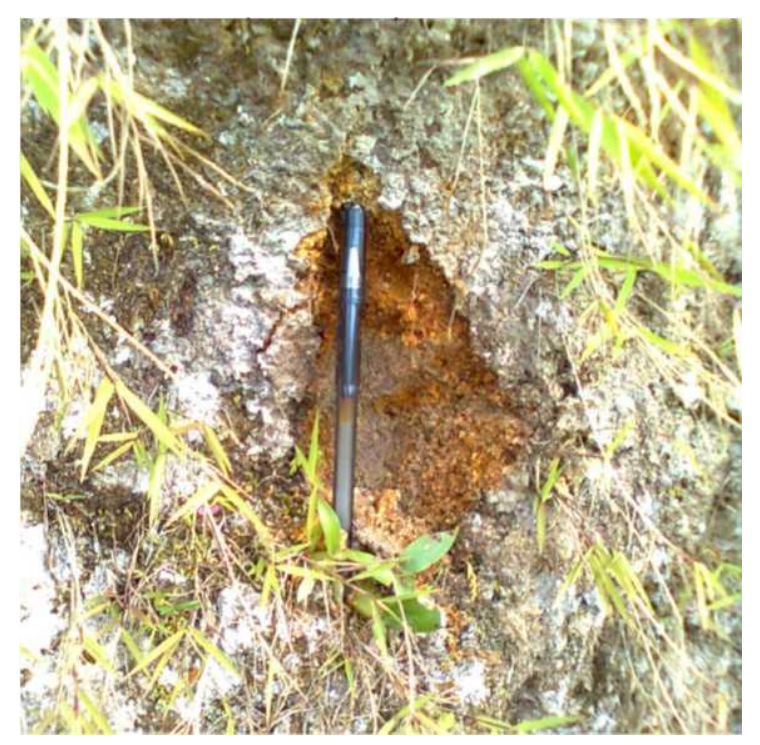

Gambar 3. Singkapan Tuf pasiran 
Tuf pasiran di daerah penelitian merupakan endapan darat (Koswara dan Santoso, 1995) yang merupakan bagian dari Formasi Ranau (Amin dkk., 1993) dan dikenal dengan nama Tuf Liwa (Koswara dan Santoso, 1995) berumur Pliosen - Plistosen. Endapan ini tersebar di dataran tinggi lembah Liwa dan memanjang dengan arah barat-timur (Koswara dan Santoso, 1995). Berdasarkan pemetaan yang dilakukan oleh Pemerintah Daerah Propinsi Lampung tahun 2000 serta Supriadidjaja dkk. (2004) di berbagai daerah di Lampung Barat, didapatkan penyebaran tuf pasiran dengan luas rata-rata sekitar $778 \mathrm{Ha}$.

\section{Sifat Fisik dan Teknik Tuf Pasiran}

Penelitian sifat fisik dan teknik tuf pasiran telah dilakukan oleh Anwar dkk., 1994 serta Anwar dan Kesumadharma, 1995. Secara umum tuf pasiran memiliki nilai Qc 0,5-10 MPa dan N-SPT 2-15 (lepas-lepas sampai agak padat) (Tabel 1). Berdasarkan analisis ukuran butir dan klasifikasi USCS, tuf pasiran termasuk kedalam jenis SP (sand poorly graded). Hasil penelitian laboratorium menyatakan bahwa tuf pasiran memiliki kohesi 0 $\mathrm{kg} / \mathrm{cm}^{2}$, sudut geser dalam berkisar antara $34-37^{\circ}$ dengan nilai UCS $140-206 \mathrm{kN} / \mathrm{m}^{2}$ (keras) (lihat Tabel 1).

Tabel 1. Karakteristik Fisik dan Teknik Tuf Pasiran (Anwar dkk., 1994 serta Anwar dan Kesumadharma, 1995)

\begin{tabular}{|c|c|c|c|c|c|c|}
\hline 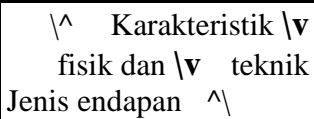 & Nilai Qc (MPa) & $\begin{array}{c}\text { N-SPT } \\
\text { (pukulan) }\end{array}$ & USCS & $\mathrm{c}\left(\mathrm{kg} / \mathrm{cm}^{2}\right)$ & $0\left(^{\circ}\right)$ & $\begin{array}{c}\mathrm{UCS} \\
\left(\mathrm{kN} / \mathrm{m}^{2}\right)\end{array}$ \\
\hline Tuf pasiran & $0,5-10$ & $2-15$ & SP & 0 & $34-37$ & $140-206$ \\
\hline
\end{tabular}

\section{Pembuatan Batako Tuf}

Pembuatan batako dilakukan melalui pencampuran tuf pasiran dengan bahan lain seperti kapur, semen, dan bambu dengan formula dan perbandingan tertentu (Tabel 2). Masing-masing formula dibuat 10 batako dengan dimensi panjang $21 \mathrm{~cm}$, lebar $10 \mathrm{~cm}$, dan tinggi 6,5 cm (Gambar 4). Setelah batako dibuat, kemudian batako tersebut dibentuk menjadi benda uji untuk uji kuat tekan bebas.

Tabel 2. Formula Campuran Untuk Pembuatan Batako Tuf

\begin{tabular}{|c|c|c|l|l|}
\hline \multirow{2}{*}{$\begin{array}{c}\text { Formula } \\
\text { No }\end{array}$} & \multicolumn{4}{|c|}{ Perbandingan Bahan Campuran } \\
\cline { 2 - 5 } & Tuf pasiran & Kapur & Semen & Bambu \\
\hline 1 & 32 ember & 4 ember & 1 ember & 1 batang \\
\hline 2 & 16 ember & 3 ember & 1 ember & 1 batang \\
\hline 3 & 16 ember & 4 ember & 1 ember & 1 batang \\
\hline
\end{tabular}


Keterangan: ember yang digunakan adalah ember dengan isi 5 liter, bambu yang digunakan 1 batang, dipotong - potong menjadi bambu berukuran $2 \times 15 \mathrm{~cm}$. Jumlah potongan disesuaikan dengan banyaknya batako yang dibuat.

Berdasarkan hasil pengujian kuat tekan langsung (Gambar 5 dan Tabel 3), dapat diketahui bahwa pada setiap formula menunjukkan adanya peningkatan nilai kuat tekan seiring dengan lamanya penirisan, yaitu menghasilkan kuat tekan berkisar antara 29-61 $\mathrm{Kg} / \mathrm{Cm}^{2}$.
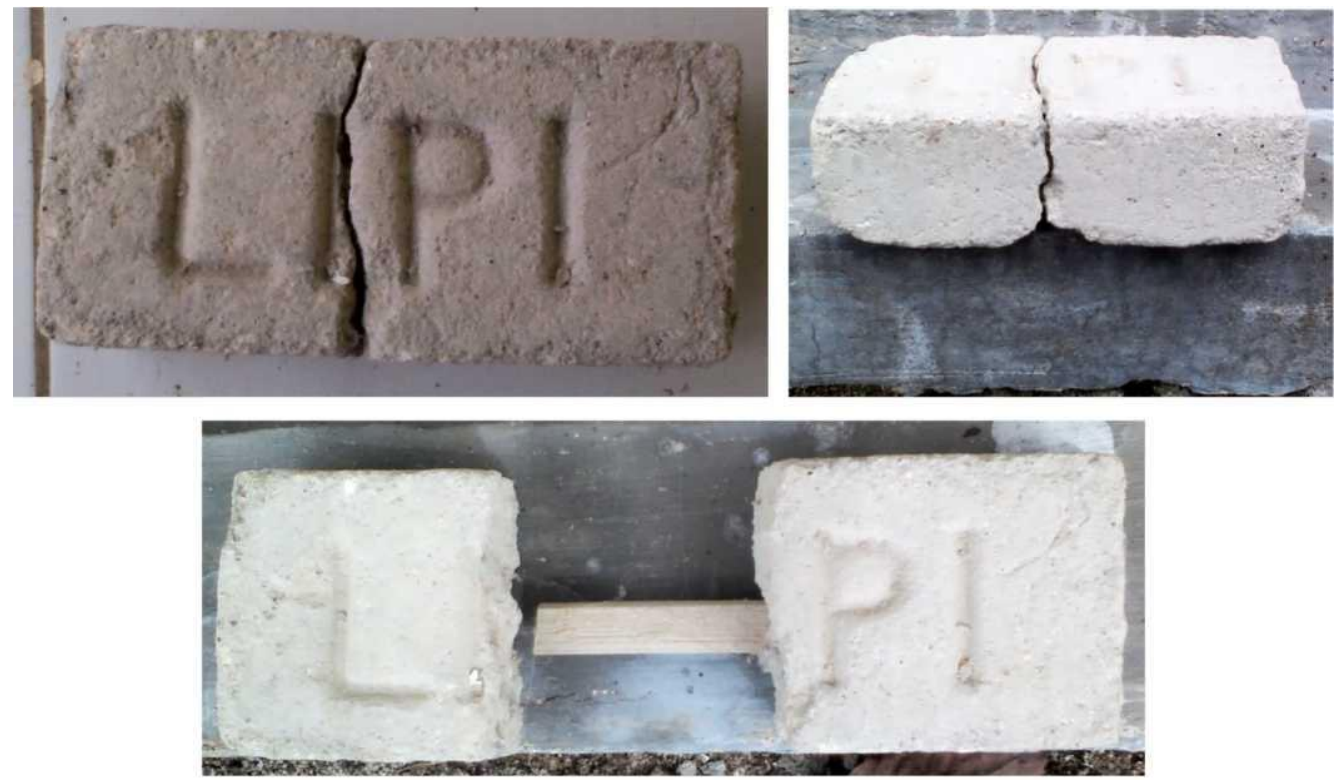

Gambar 4. Batako Tuf

Grafik hasil pengujian kuat tekan langsung menggambarkan adanya kecenderungan kenaikan nilai kuat tekan bebas jika batako ditiriskan selama 7-21 hari. Khususnya pada batako yang ditiriskan selama 21 hari, maka akan didapatkan nilai kuat tekan bebas yang besar. Hal ini menunjukkan bahwa semakin tiris atau kering, maka ikatan antar partikel penyusun batako semakin kompak dan kuat, sehingga kuat tekan akan semakin besar. Secara keseluruhan nilai kuat tekan pada percobaan pembuatan batako menunjukkan nilai di atas standar bahan bangunan yang telah ditetapkan (Munandar, 1994), yaitu berkisar dari 17-61 Kg/ $\mathrm{Cm}^{2}$. 


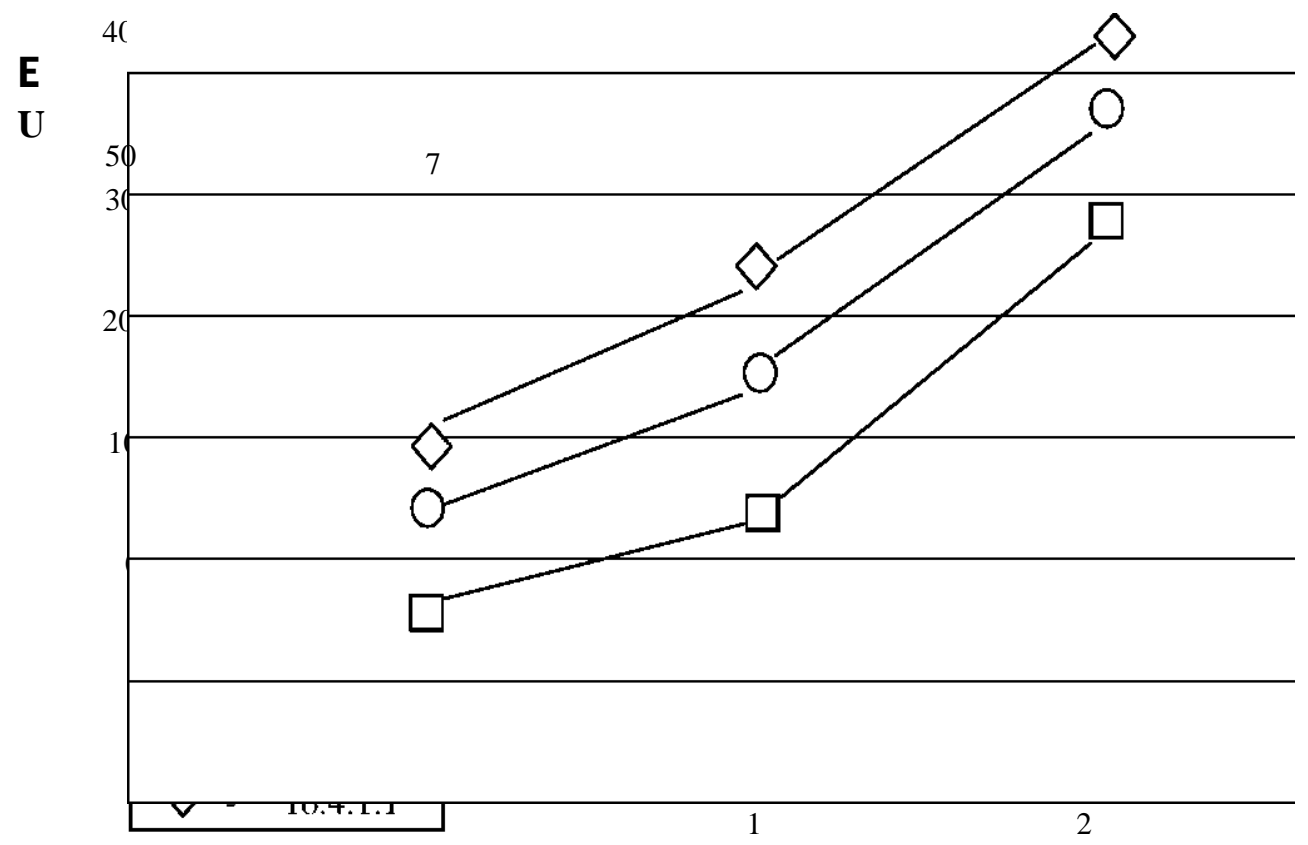

Gambar 5. Grafik Hasil Pengujian Kuat Tekan Bebas Batako Tuf

Tabel 3. Hasil Pengujian Kuat Tekan Bebas Batako Tuf

\begin{tabular}{|c|c|c|c|c|c|}
\hline \multirow{2}{*}{ Formula No } & \multicolumn{4}{|c|}{ Perbandingan Bahan Campuran } & \multirow{2}{*}{$\begin{array}{c}\text { Kuat Tekan } \\
\left(\mathrm{Kg} / \mathrm{Cm}^{2}\right)\end{array}$} \\
\hline & Tuff pasiran & Kapur & Semen & Bambu & \\
\hline 1 & 32 & 4 & 1 & 1 buah & $17 *-23 * *-48 * * *$ \\
\hline 2 & 16 & 3 & 1 & 1 buah & $22 * .35 * * .57 * * *$ \\
\hline 3 & 16 & 4 & 1 & 1 buah & $29 *, 43 * *, 61 * * *$ \\
\hline
\end{tabular}

Keterangan: *

Pengeringan 7 hari $* *$

Pengeringan 14 hari $* * *$

Pengeringan 21 hari

\section{DISKUSI}

Secara geologi, tuf pasiran adalah endapan produk gunungapi Kuarter yang diendapkan di lingkungan darat dan merupakan bagian dari Formasi Ranau atau lebih dikenal dengan nama Tuf Liwa. Endapan ini tersebar di dataran tinggi lembah Liwa dan memanjang dengan arah barat-timur dengan luas rata-rata 778 Ha. Berdasarkan uji keteknikan, pembuatan batako, dan uji kuat tekan bebas yang telah dilakukan terhadap tuf pasiran, mengindikasikan bahwa endapan ini dapat dipakai sebagai bahan galian alternatif, khususnya dapat digunakan sebagai bahan bangunan (batako, paving blok, dan sebagainya). Pemanfaatan bahan galian ini akan mengurangi ketergantungan terhadap pemakaian endapan lain yang selama 
ini digunakan untuk bahan baku batu bata sebagai bahan bangunan utama di daerah Liwa dan sekitarnya.

\section{KESIMPULAN}

Pada percobaan pembuatan batako tuf yang telah dilakukan menghasilkan nilai kuat tekan berkisar antara $29-61 \mathrm{Kg} / \mathrm{Cm}^{2}$. Berdasarkan standar nilai bahan bangunan, maka nilai yang didapatkan adalah nilai yang diatas standar nilai bahan bangunan. Hal ini mengindikasikan bahwa tuf pasiran dapat dipakai sebagai bahan bangunan alternatif, tentu saja dicampur dengan bahan - bahan yang lain dan dengan formula pencampuran yang tepat.

\section{DAFTAR PUSTAKA}

Amin, T.C., Sidarto, Santosa, S., dan Gunawan, W. 1993., Peta Geologi Lembar Kotaagung Sumatera, Pusat Penelitian dan Pengembangan Geologi

Anwar, H.Z., Edi, S., Sudaryanto, dan Rukmana, I., 1994. Karakteristik enjinering lapisan tufa pasiran dan tanah residu di daerah Liwa dan sekitarnya, Proceedings Ekspose Ilmiah Psulitbang Geoteknologi-LIPI, 1

Anwar, H.Z., dan Kesumadharma, S., 1995. Penyelidikan geoteknik pada lapisan tufa pasiran di Karang Menang, Padang Dalom, Liwa, Prosiding Hasil-Hasil Penelitian Puslitbang Geoteknologi LIPI

Badan Standardisasi Nasional., 2008. Tata Cara Pembuatan Benda Uji di Laboratorium Mekanika Batuan. SNI 2848:2008

Dini, B., Abidin, N., Gunawan, A., dan Wahyudin, A., 2008. Pemanfaatan Limbah Kayu dan Sekam Padi Sebagai Campuran Pembuatan Bata Tufa di Lampung. Laporan Penelitian. UPT LUTPMB LIPI - Liwa. LIPI

Hartono, T., Riadi, A.S., Mulyono, A., Rukmana, I., Sutardi, N., Baidilah, M., Usman, M., dan Rusmana., 2004. Implementasi Uji Kualitas dan Pengembangan Bahan Galian Batu Tufa Lampung. Laporan Penelitian. UPT LUTPMB LIPI - Liwa. LIPI

Hartono, T., Sudarsono, Rhazista, Mukti, M.M., dan Tatang, A., 2005. Konstruksi Bangunan Tahan Gempa Menggunakan Bata Tufa 
Bertulang Bambu di Daerah Lampung. Laporan Penelitian. UPT LUTPMB LIPI - Liwa. LIPI

Koswara, A., dan Santoso., 1995. Geologi rinci daerah Liwa Lampung Barat Sumatera Selatan skala 1:50.000, Jurnal Geologi dan Sumberdaya Mineral, VI

Müller, Claudia., Eva Fitriani, Halimah, dan Ira Febriana., 2006. Modul Pelatihan Pembuatan Ubin atau Paving Blok dan Batako. International Labour Office. Jakarta

Munandar, M., 1994. Laporan Pengkajian Bahan Bangunan di Liwa untuk Perumahan. Pusat Penelitian dan Pengembangan Pemukiman

Pemerintah Daerah Propinsi Lampung., 2000. Rencana Strategis Pengelolaan Wilayah Pesisir Lampung. Bandar Lampung

Shirley., 1994. Penuntun Praktis Geoteknik dan Mekanika Tanah. Nova. Bandung

Supriadidjaja, A., Gurharyanto, Sumarnadi, E.T., Kusmayadi, E., 2004. Karakterisasi Limbah Tuff pasiran Untuk Pembuatan Beton Ringan Cetak Tuang. Laporan Penelitian. UPT LUTP Jampang Kulon. LIPI

http://www.maps.google.co.id diakses pada tanggal 1 April 2013 